\title{
RELAŢIILE ISLAMULUI CU TERITORIILE ROMÂNEŞTI
}

\section{Angel Mihai CIURTIN*}

\begin{abstract}
The relations of Islam with the Romanian territories ${ }^{1}$. Antichrist A famous and contemporary prophecy of the French writer Andre Malraux (1901-1976) says: „The XXI century will be religious or not at all". We do not know if he referred at Islam or not but from the three monotheistic religions today: Judaism, Christianity and Isla m, the evolution of the latter seems to incline the balance towards a century preoccupied of religious kneading. Islam, the youngest of the three monotheistic religions proves to have an exceptional immunity to the tendency of desacra lization of modern societies among which coexists. Like all the other religions, Islam was not exempted from fractures and innerfights which led to what we have today: Sunni and Shia Islam. There is a nother split that has to do with the Romanian lands: Arab and Turkish Islam. The last one represents the way by which the Islam went through the Romanian lands around the XIII century. A question that deserves an answer- the model of the historical good cohabitation between Christians and Muslims of Romania will remain the same in the context of the new Arab Islamic newcomers?
\end{abstract}

Keywords: Islam, Arab, Turk, Tatar, Romanian, faith, coexistence.

\section{Introducere}

Islamului în România îi corespunde în anul 2019 un procent de 0 , 3 la sută din populația țării. Acest procent ar face, la prima vedere, pe oricine să creadă că un subiect privitor la o analiză a situației musulmanilor din România este prea puțin interesant pe fondul unei

"Priest, PhD Student, Faculty of Orthodox Teology at „1 Decembrie 1918” University, Alba Iulia, Romania.

${ }^{1}$ Studiu redactat sub îndrumarea Pr. Prof. Univ. Dr. Emil Ioan Jurcan, care şi-a exprimat acordul pentru publicare. 
majorități covârșitoare a creștinilor. Cazul aparte al musulmanilor din România reprezintă, din perspectiva a tot mai mulți analiști, un model testat istoric şi funcțional de conviețuire religioasă şi etnică a reprezentanților celor trei religii monoteiste: islamul, creștinismul și iudaismul. Atunci când vorbim despre Islam în România de azi trebuie ştiut că majoritatea musulmanilor din România se află în Dobrogea, cu precădere în orașele Constanța și Tulcea.

În prezent, conform datelor recensământului din anul 2011, în România trăiesc 67.566 de cetăţeni care s-au declarat ca fiind de religie musulmană. Dintre aceştia, marea majoritate $(85 \%)$ locuiesc în judeţulConstanţa, apoi (12\%) în Tulcea, restul în oraşe precum Bucureşti, Călăraşi, Brăila, Galaţi şi Drobeta-Turnu Severin, dar și în oraşe precum Cluj-Napoca, Alba etc.

Cu o vechime de peste 700 de ani, comunitatea musulmană din România s-a constituit inițial pe un nucleu etnic de origine turcă, consolidat către secolul al XIX-lea prin adăugarea etniei tătare în urma imigrației dinspre Crimeea. Dar există presupuneri conform cărora elementul musulman ar fi pătruns chiar mai devreme în regiunea dintre Dunăre şi Marea Neagră, unde tătarii și strămoșii lor, cumanii (kipceaci), sunt atestaţi de aproape un mileniu. Pe parcursul timpului nu se consemnează vreo mișcare deosebită în direcția prozelitismului, lucru explicabil mai mult din rațiuni economice: imperiul avea nevoie mai mult de resursele oferite de regiunile cucerite decât de noi convertiți, iar, conform Coranului, unui musulman nu îi este permis să ia bir sau să stăpânească pe un alt musulman.

Deși Principatele Române plăteau bir și erau obligate să trimită diferite produse alimentare Porții, pentru susținerea nevoilor armatei, ele beneficiau de autonomie în multe privințe: economică, administrativă și pe plan religios. În anul 1417 şi în anul 1489, Mircea cel Bătrân în Ţara Românească, respectiv Ștefan cel Mare în Moldova, au semnat tratate prin care își recunoșteau supunerea față de Poartă, dar situația faptică de suzeranitate față de Istanbul era doar cu numele. În ceea ce privește Transilvania, aceasta a suferit cea mai puțină influență musulmană(1541 1688), având statut special de autonomie statală. Istoricul clujean Călin Fezeleu arată că timpul petrecut de Transilvania sub dominația otomană a fost unul mult mai favorabil decât cel de sub stăpânirea austro-ungară, 
deoarece teritoriul acesteia s-a mărit, adăugându-i-se Maramureșul, Banatul și Partium (Sălajul, Sătmarul, Oradea și Aradul) ${ }^{2}$.

Astăzi, comunitatea musulmană tătară din România e alcătuită din urmașii tătarilor care au trebuit să părăsească Crimeea în secolul al XVIIIlea. Hanatul tătar din Crimeea s-a aflat timp de 300 de ani sub protecția otomanilor, iar după anexarea Crimeii de imperiul Rus. În anul 1783, tătarii și-au găsit refugiu între granițele imperiului Otoman, inclusiv în Dobrogea, care era sub stăpânire turcă încă din anul 1418, după moartea lui Mircea cel Bătrân.

Islamul din România a fost de la bun început sunnit și, venind pe filiera turcească, de orientare hanefită, adică mai permisiv şi mai tolerant ${ }^{3}$. Această particularitate a islamului de orientare hanefită a contribuit mult la armonizarea preceptelor islamice cu credința creștinilor autohtoni până în zilele noastre.

Pentru a înțelege mai bine specificul Islamului tradițional hanefit din România trebuie să facem apel la începuturile Imperiului Otoman, de a cărui istorie se leagă atât de mult istoria românilor din cele trei provincii românești: Țara Românească, Moldova și Transilvania, dar în special Dobrogea, leagănul începuturilor musulmanilor din România.

\section{Apariția otomanilor și despre Sufi}

Marile migrații care au dat naștere imperiilor Selgiucid, Mongol și Timurid din Iran au provocat apariția mai multor imperii musulmane vestice. Tribul Oghuz, care a pus bazele imperiului Selgiucid în Iran și în Irak, și-a deschis drum înspre Georgia, Armenia și Anatolia bizantină. În bătălia de la Manzikert din anul 1071, turcii i-au învins pe bizantini, luându-l prizonier chiar pe împăratul Romanos I. În secolul următor, ei sau răspândit de-a lungul Asiei Mici și au format un alt stat și o altă societate selgiucidă. Aceste triburi migratoare erau organizate în grupuri mici de războinici numiți „ghazi”, sub conducerea unor căpetenii numite „bei” sau sufis, un fel de sfinți, „,baba”.

${ }^{2}$ Călin Fezeleu, Principatul Transilvaniei în epoca suzeranităţii otomane (1541-1688), Cluj-Napoca. Edit. Byibliotek, 2013, p. 28.

${ }^{3}$ Hanefismul îl are ca fondator pe Abu Hanifa, născut în Kufa (700-767). Această școală hanefită a influențat islamul din Turcia precum și din majoritatea regiunilor aflate sub dominație otomană, în consecință și Dobrogea. 
De fapt istoria chiar consemnează prezența unui astfel de „sufi’' în zona Dobrogei, care ar fi pus bazele Islamului în zonăși al cărui mormânt se află la Babadag. Este vorba despre dervişul ghazi Sari Saltuk Baba de pe la jumătatea secolului al XIII-lea. Considerat părintele și fondatorul orașului Babadag, Sari Saltuk Baba Dede este personajul legendar despre care se spune că a fost conducătorul a 10.000 de familii de turci selgiucizi împreună cu care ar fi venit în regiunea Dobrogei în anii 1263 și 1278, cerând împăratului bizantin de la acea vreme dreptul de a se așeza în regiune. Lua astfel naștere orașul Babadag de azi, care îiși poartă numele. Sari Saltuk a rămas în fruntea comunitătii sale până la moartea sa în anul 1304.

În general, sufiții din mediul rural au adoptat o atitudine tolerantă faţă de creștini, fapt care a facilitat convertirea populațiilor grecești și armene la islam. Datorită faptului că în Coran există referințe numeroase la adresa lui Hristos, aceștia aveau un respect deosebit la adresa Lui dar și la adresa Fecioarei Maria. În Coran, Hristos este Mesia, Cuvântul întrupat al lui Dumnezeu:

Dacă Coranul îl numește pe Mahomed „Pecetea Profeților”, unii sufiți îi atribuie lui Iisus calitatea de „Pecetea Sfințeniei”. Într-o celebră carte intitulată Revelațiile Meccane, Muhyi d-Din ibn Arabi, poet și sufist, mărturisește că:

„Pecetea sfințeniei universale, deasupra căreia nu mai există altceva sfânt, este Domnul nostru Iisus" .

\section{Despre Otomani}

Între anii 1242-1243, invazia mongolilor şi victoria împotriva selgiucizilor, soldată cu transformarea lor în vasali, înclină balanța puterii în Anatolia dinspre statul central înspre populațiile de războinici. Odată cu invaziile mongole au intrat alte triburi turcice (turkmenii), care s-au așezat în zonele muntoase de la frontiera cu imperiul bizantin. Dintre toate aceste state de frontieră, cel condus de Ertugul și de fiul său Osman, cu capitala la Soyut, va schimba cursul istoriei pentru aproape 500 de ani. Acest Osman (Othman), numit de tatăl său dupănumele celui de-al doilea calif -Uthman-, va fi considerat întemeietorul dinastiei otomane.

${ }^{4}$ William StodDart, Outline of Sufism, Bloomington, Edit. World Wisdom inc., 2012, p. 58. 
După cutremurul din anul 1357, care a dărâmat cetatea din Gallipoli, acesta a fost părăsit aproape total de populația autohtonă greacă, moment de maximă importanță, fiindcă de acum otomanii aveau acces spre Europa. Turcii nu au stat prea mult pe gânduri și s-au așezat aici, reconstruind cetatea și punând piatra de temelie pentru ceea ce avea să devină mai târziu un imperiu multietnic și multiconfesional ${ }^{5}$.

De aici a fost puțin până când masele de războinici turci au intrat în Balcani și au ocupat nordul Greciei, Maced onia și Bulgaria. Controlul vestului Balcanilor a fost decisiv după bătălia de la Kosovo, din anul 1389. Odată pusă baza Imperiului Otoman pe pământ european, au început planurile pentru cucerirea Constantinopolului. După cruciada din anul 1396, care s-a încheiat tragic pentru creștini prin înfrângerea de la Nicopole, Dobrogea trece în anul 1417 sub stăpânire otomană.

Profesorul universitar dobrogean Ibram Nuredin (1943-), profesor la Universitatea „Ovidius” din Constanța, a scris mai multe studii despre istoria comunității turco-tătare din țara noastră. Din cercetările dânsului aflăm că în anul 1223 nepotul lui Ginghis Han, Batu Han, îi învinge pe ruși, iar Hanatul întemeiat de el, Hoarda de Aur, își va extinde autoritatea și asupra Dobrogei. Una din primele mențiuni despre existența tătarilor în Dobrogea o găsim într-un document de pe vremea sultanului Mahomed al II-lea și face trimitere la epoca lui Ginghis Han, când șefului tătar Ebruz-ata i-a fost dăruit un domeniu din zonă.

În Dobrogea, comunitatea tătarilor este formată în principal din două grupuri de tătari: grupul nogaic și grupul crimeean. Cel mai mare grup de tătari s-a stabilit în Dobrogea în timpul lui Timurlenk (13901405). După dispariția lui Nogay (1299) și moartea lui Sari Saltuk (1300), o parte din grupul selgiucizilor s-a întors în Anatolia, iar cei rămași au trecut la creștinism, probabil în urma presiunilor misionarilor bizantini, alături de alte grupuri de pecenegi, cumani și alte grupuri mai vechi, formând o comunitate ce există și azi sub numele de „găgăuzi”, adică creștini ortodocși vorbitori de limbă turcă. Aceștia sunt astăzi prezenți în nord-estul Bulgariei și în Republica Moldova.

Odată cu intrarea sub stăpânire otomană, Dobrogea devine dar-alIslam, adică pământ supus regulilor islamice, ceea ce a dus la răspândirea

\footnotetext{
${ }^{5}$ Stephen O`SHEA, Sea of Faith, New York, Walker \& Company, 2006, p. 243.
} 
influenței turco-musulmane în toate aspectele vieții. Treptat, în Dobrogea se extindeau și diferitele instituţii sau organizații specifice otomanilor: școli religioase islamice, mektep-uri și medrese de orientări filosofice diferite numite ,tarikat”-uri. De remarcat longevitatea seminarului Gazi Ali Paşa înființat în anul 1610, care a avut o activitate de aproximativ trei secole şi care în ciuda unei mici întreruperi funcționează și astăzi, pregătind personalul clerical pentru comunitățile musulmane din România.

După înfrângerea suferită de țarul Petru cel Mare în anul 1711 pe malurile Prutului în fața otomanilor, Dobrogea nu a mai cunoscut liniștea și a început să simtă tot mai puternic presiunea rușilor în contextul războaielor interminabile dintre aceştia şi turci. Ca urmare a confruntărilor militare tot mai dese: 1735, 1769, 1786, 1806, 1853 și 1877, populația Dobrogei s-a redus treptat, iar unii musulmani au început să emigreze înspre centrul Imperiului Otoman. Având în vedere importanța așezării strategice dintre Dunăre și Marea Neagră a Dobrogei, Poarta Otomană a făcut eforturi pentru a o menține între granițele imperiului. Astfel, amintim că în urma vizitei sultanului Abdul Medgid (1839-1861), un val migrator important de cerchezi a fost aşezat la Medgidia, unde sultanul a construit o geamie funcțională și astăzi ${ }^{6}$.

După revenirea Dobrogei la România, statutul comunităţii musulmane de aici se va schimba radical. După anul 1878, dintr-o comunitate majoritară cu un statut privilegiat, devine comunitate minoritară în cadrul unui stat și popor cu o cultură diferită, o altă limbă pe care o cunoștea puțin și o altă religie. De acum, influența noului cadru istoric va duce tot mai mult înspre un proces de românizare și adaptare la noile realități. Comunitatea turco-tătară musulmană se va enclaviza tot mai mult pentru a-și păstra identitatea de etnie, limbă și religie în raport cu majoritatea românească.

Referitor la patrimoniul religios administrativ, Muftiatul Cultului Musulman din România are astăzi 81 lăcașuri de cult, din care în municipiul și județul Constanța o moschee, 66 geamii, 4 mesgiduri, în municipiul București 2 geamii și în județul Tulcea 8 geamii.

Personalul clerical era format la Seminarul musulman din Medgidia unde s-a mutat în anul 1901 din Babadag; aici fusese înființat

${ }^{6}$ Ibidem, p. 27. 
încă din anul 1610. Astăzi, personalul clerical se formează la același seminar, dar și în alte țări, având studii universitare efectuate în: Iordania, Sudan, Arabia Saudită sau Turcia ${ }^{7}$.

\section{Islamul tradiționalist indigen din România și provocările noilor musulmani}

În contextul migrației musulmane recente spre țările cele mai dezvoltate ale Europei și nu numai, pe fondul discuțiilor la nivel politic tot mai aprinse și tensionate privind responsabilitatea tuturor țărilor membre UE de a primi cote clare de astfel de imigranți, iată că apare tot mai des pomenitul modelul unic de înțelegere și de bună conviețuire a celor trei religii monoteiste din Dobrogea.

Astăzi, situația comunității musulmane din România este considerată a fi unică, cel puțin în Europa, datorită climatului excepțional de interculturalitate și dialog interconfesional. Acest ambient caracterizează toate cele trei culte monoteiste din România: cel creștin, cel musulman și cel iudaic. În principal, această toleranță se datorează modului cum aceste trei culte s-au raportat de-a lungul istoriei comune pe aceste teritorii românești la textele scripturistice fondatoare: Biblia, Coranul și Tora. În România putem afirma că nu a existat vreodată vreun conflict major între comunitățile celor trei culte principale monoteiste.

Acest model, să-1 numim dobrogean, de conviețuire interreliogioasă și interetnică, bazat pe un permanent dialog și schimb cultural, Muftiul Yusuf Murat, reprezentantul oficial și recunoscut de către Statul Român al comunității musulmane din România, pare ferm hotărât să-l apere, paradoxal, în fața unui segment nou adăugat comunității musulmane din România: noii musulmani veniți în România după anul 1989 din țări arabe. Într-o intervenție televizată, Muftiul Yusuf Murat afirmă următoarele:

„Trebuie să se știe, că eu chiar da că o să plec din fotoliul de la Muftiat, de altfel nu-l mai vreau, ei nu o să poată schimba în vreun fel atmosfera de aici. Chiar dacă voimaifi sau nu Muftiu, nu le voi permite acest lucru. Prietenii mei nu-i vor lăsa să schimbe ceea ce ne-a rămas de atâtea secole

${ }^{7}$ Ibram Nuredin, Islamul pur şi simplu. Musulmanii din România, Constanța, Edit. Golden Print, 2016, p. 154. 
de la străbunii noștri. Asta trebuie să știe și ei. România, în speță Dobrogea, a colo unde sunt cei maimulți musulmani, va rămâne un model bun în viața socia lă, un model de conviețuire nemaiîntâlnit nică ieri”" ${ }^{8}$.

Una dintre acuzațiile aduse de Muftiul Yusuf Murat, ONG-urilor netradiționaliste din ultima vreme este și aceea că editează și traduc în limba română, pentru noii convertiți, materiale și cărți ale unor autori reprezentativi pentru islamul fundamentalist, care au adus atâtea deservicii modului în care este privit astăzi Islamul în întreaga lume. Un exemplu de carte al cărei conținut a fost adus în discuție de către Muftiul Yusuf se numește Islamul și celălalt de Muhammad Imarah. Așa cum reiese și din titlul cărții, se observă „orientalismul inversat, ierarhic și ofensator" ". Totuşi, reprezentanţii ONG-urilor au continuat să recomande cartea cu mândrie chiar și după admonestarea Muftiului, negăsind nimic ideologic deviant sau periculos în textul propus ${ }^{10}$.

Dacă pentru comunitatea turco-tătară autohtonă, moștenirea culturală şi religioasă, preluată sub forma adaptării la realitățile istorice, este un bun care i-a ajutat să coexiste cu majoritatea românilor, pentru promovatorii noului islam toate acestea reprezintă forme ale ereziei care te scot în afara Islamului. Însuşi Muftiul este acuzat de lipsuri mari în cunoaşterea Islamului pur, de perpetuarea unor tradiţii (bidah) locale eretice, de anacronism în predicile ținute de el şi de imamii asociaţi lui și de prea multă toleranță în relaţiile cu cei de alte religii ${ }^{11}$.

Pe parcursul istoriei cultului musulman, modul în care s-au raportat credincioșii la preceptele Coranului și ale Sunnei a fost unul nu tocmai constant. Coranul are versete care îndeamnă la pace și înțelegere, dar și versete care îndeamnă la violență, numite ,,versete ale sabiei”. Însuşi profetul Mahomed a recunoscut în câteva rânduri că a fost înșelat de diavol în revelațiile sale și s-a văzut nevoit să abroge unele afirmaţii făcute.

${ }^{8}$ https://www.google.com/search?q=interviu+cu+yussuf+murat\&oq=interviu+cu+yussuf +murat\&aqs=chrome..69i57.16137j0j8\&sourceid=chrome\&ie=UTF-8 $\quad$ accesat la data de: 18. 09. 2019).

${ }^{9}$ Ibram Nuredin, Islamul pur și simplu. Musulmanii din România, p. 330.

${ }^{10} \mathrm{https}$ ://www.lapunkt.ro/2015/02/despre-kippah-muftiului-sau-prevenirea-rad icalizariimusulmanilor-din-romania/ (accesat la data de: 18. 09. 2019).

11 Muftiul este acuzat de trecere la creștinism pentru faptul că a urmat cursurile unui doctorat în drept canonic la Facultatea de Teologie Ortodoxă din Târgoviște. 
De asemenea, o analiză istorică și religioasă cu privire la modul cum au evoluat școlile de interpretare islamice în timpul expansiunii musulmane arabe, în comparație cu expansiunea islamică sub turci, ne va arăta o diferență destul de mare în modul de abordare a lumii nemusulmane din perspectivă islamică. În timpul cuceririlor arabe, islamul arab era asimilator și arabizator (de exemplu, Egiptul până astăzi vorbește limba arabă carenui limba maternă a egiptenilor), Coranul trebuia studiatîn limba arabă, limba arabă este limba vorbită în paradis etc.

Am aşezat în antiteză cele două tipuri de Islam: cel arab cu cel turcesc, pentru a înțelege de ce astăzi avem o luptă în interiorul Islamului mondial între lumea arabă şi islamul turcesc. Este clar că există o bătălie pentru asumarea rolului de protector al musulmanilor din lumea întreagă, luptă care a început să aibă în vizor și comunitatea de musulmani din România. Muftiatul din România, prin vocea reprezentantului legal și oficial, Yusuf Murat, are o colaborare foarte bună cu Turcia, țară care chiar și în timpul comunismului a fost protectoarea comunităţii turco-tătare din România.

Din spusele Muftiului, acesta colaborează și cu state arabe, dar a cerut acestora să nu amestece problemele islamului din alte țări cu modul exemplar de conviețuire a comunității sale din România, deoareceislamul practicat de aceia nu se potrivește aici și riscă să tensioneze relațiile cu comunitatea românească:

„Problema la noi provine de la o interpreta re diferențiată a Islamului în rândul sunniților. Este drept că există mai multe școli de drept, de jurisprudență isla mică. Pe lângă acestea, însă, în ultimul secol au început să apară și unele idei religioase specifice anumitor învățați și de aici rezultă și problema de bază care ar consta în neînțelegerea între sunniți. Despre neînțelegeri între sunniții și șiiții din România nu se poate pune problema deoarece în a cest caz a vem de-a face cu un respect reciproc. Dar neînțelegerea dintre sunniți creează deja o stare de disensiune între musulmani care se datorează ideilor diferite şi abordărilor diferite. Până în jurul anului 1995 în România nu au fost astfelde probleme. De atunci, însă, au început să prindă putere și să înflorească a numite ideișii influențe în cadrul comunitățiimusulmane din România"12.

${ }^{12} \mathrm{http}$ ://interetnica.ro/muftiul-muurat-iusuf-ex ista-dif erenta-de-in terpretare-islamu lui-inrandul-sunitilor-din-romania/ (accesat la data de: 18. 09. 2019). 


\section{Concluzii: Comunitatea turco-tătară încotro?}

Pe parcursul acestui studiu, ne-am străduit să demonstrăm că Islamul practicat în Dobrogea este un islam aparte, care de 700 de ani s-a aflatîn armonie cu populația româneascăși religia creștină de aici. Lucrul acesta este cu atât mai admirabil cu cât, în perioada în care Dobrogea s-a aflat între granițele Imperiului Otoman iar comunitatea turco-tătară era net majoritară, această conviețuire a existat la fel de bine.

Timpul a demonstrat aici că, indiferent de cine este majoritar etnic sau religios în Dobrogea, valorile umane de bună conviețiire, izvorâte și din respectarea exigențelor religioase ale fiecăruia, au existat în mod natural și nu impuse de vreo instanță externă. Această naturalețe a acceptării celuilalt în diversitatea lui constituie elementul esențial în căutarea soluțiilor la problemele societății europene și nu numai.

Așa cum reiese din confruntarea datelor despre islamul de azi din România, viitorul acestuia va fi clar influențat de aceea parte care va reuși să ofere discursul public cel mai bine ancorat în realitățile actuale, oferind în același timp răspunsuriși perspective constructive menținerii identității etnice și religioase și fără a se uita reperele istorice care au aţâțat fiabilitatea și funcționalitatea a ceea ce am numit pe parcursul acestui studiu „Islamul dobrogean”.

Oamenii din Dobrogea au înțeles că dușmanul lor nu este „Celălalt”, fie el creștin, evreu sau altceva, ci intoleranța, prejudecățile, orgoliile și, mai ales, fundamentalismul promovat în ultimul timp. Avertismentele repetate ale Muftiului Yusuf Murat, în privința germinării activităților unor ONG-uri islamice cu orientare fundamentalistă, trebuie luate în serios de către autoritățile române, iar acest conflict merită o analiză mai profundă deoarece va avea un impact major asupra modului în care comunitatea musulmană din România este obligată să-și reconstruiască identitatea, dar și asupra felului în care aceasta va fi percepută de către societatea românească. O bună conviețuire între religii trebuie să pornească de la următoarea axiomă: „Nu există pace în lume fără pace între religii, nu există pace între religii fără dialog între religii”(Hans Kung) ${ }^{13}$.

${ }^{13}$ Hans KUNG, In search of a new world ethic, Oxford, Edit. Wips and Stock, 1994, p. 113. 


\section{Referințe bibliografice:}

1. FEZELEU, Călin, Principatul Transilvaniei în epoca suzeranității otomane (1541-1688), Cluj-Na poca, Edit. Bybliotek, 2013;

2. http://interetnica.ro/muftiul-muurat-iusuf-exista-diferenta-deinterpretare-islamului-in-randul-sunitilor-din-romania/, (accesat la data de: 18. 09. 2019);

3. https://www.google.com/search?q=interviu+cu+yussuf+murat\&oq=inter $\mathrm{viu}+\mathrm{cu}+$ yussuf + murat\&aqs $=$ chrome..69i57.16137j0j8\&sourceid $=$ chrom e\&ie=UTF-8. (accesat la data de: 18.09. 2019);

4. https://www.lapunkt.ro/2015/02/despre-kippah-muftiului-sauprevenirea-radicalizarii-musulmanilor-din-romania/ (accesat la data de: 18. 09. 2019);

5. KUNG, Hans, In search of a new world ethic, Oxford, Edit. Wips and Stock, 1994;

6. NUREDIN, Ibram, Islamul pur și simplu - musulmanii din România, Constanța, Edit. Golden Print, 2016;

7. O`SHEA, Stephen, Sea of Faith, New York, Edit. Walkers \& Company, 2006;

8. STODDART, William, Outline of Sufism, Bloomington, Edit. World Wisdom inc., 2012. 